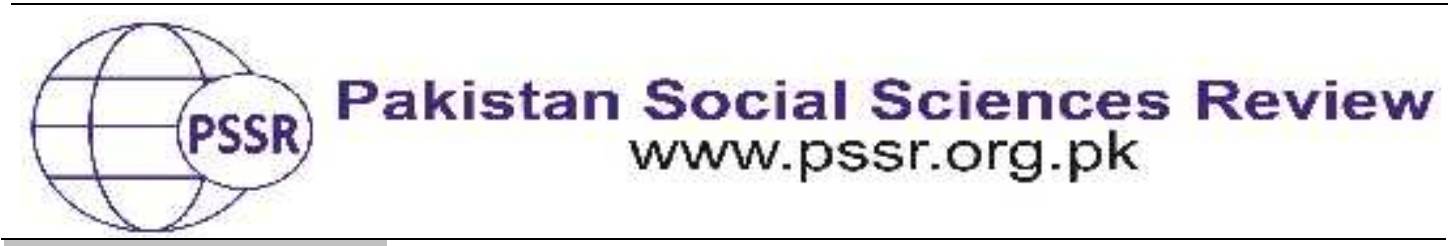

RESEARCH PAPER

\title{
Arms Rivalry in South Asia: The Prisoner's Dilemma Paradigm
}

\author{
Qasim Shahzad Gill
}

Johnson-Shoyama Graduate School of Public Policy, University of Saskatchewan, Canada

\begin{tabular}{|c|c|}
\hline PAPER INFO & ABSTRACT \\
\hline $\begin{array}{l}\text { Received: } \\
\text { October } 29,2020 \\
\text { Accepted: } \\
\text { December } 05,2020 \\
\text { Online: } \\
\text { December } 31,2020\end{array}$ & $\begin{array}{l}\text { One of the central problems in relations between Pakistan and } \\
\text { India in South Asia is the issue of cooperation. The focal point in } \\
\text { this study is the application of game theory in a situation of } \\
\text { deterrence between the two countries. The question is "Why are } \\
\text { India and Pakistan unable to stop their nuclear arms race?", as }\end{array}$ \\
\hline $\begin{array}{l}\text { Keywords: } \\
\text { Game Theory, } \\
\text { India, } \\
\text { Nuclear Arms } \\
\text { Race, } \\
\text { Pakistan, } \\
\text { Prisoner's } \\
\text { Dilemma }\end{array}$ & $\begin{array}{l}\text { building peace in South Asia would clearly be in the best } \\
\text { interests of both. Game theory provides a strong traditional } \\
\text { analysis of the Pakistan-India situation, and it clarifies how both } \\
\text { countries can find a way out of this low-paying situation. The } \\
\text { nuclear arms race between Pakistan and India can be seen as an } \\
\text { example of the "prisoner's dilemma". The objective of this } \\
\text { research is to describe all the payoff matrices of the prisoner's } \\
\text { dilemma to understand the situation comprehensivelv and find }\end{array}$ \\
\hline $\begin{array}{l}\text { Corresponding } \\
\text { Author } \\
\text { qasim.gill@usas } \\
\text { k.ca }\end{array}$ & $\begin{array}{l}\text { a way for both countries to reach the outcome of arms control in } \\
\text { their arms race. An attempt has also been made to see how the } \\
\text { United Nations' new agenda for disarmament could work in } \\
\text { this situation. }\end{array}$ \\
\hline
\end{tabular}

\section{Introduction}

Since the partition of British India in August 1947, Pakistan and India have been in an antagonistic relationship and engaged in an arms race. There have been three full-fledged wars $(1948,1965$, and 1971) and several standoffs between the two countries over different disputes. The turning point in India's decision to build an atomic bomb was its defeat by China in 1962. India tested its first nuclear weapon in May 1974 and has continued to develop nuclear weapons. Pakistan's defeat in 1971 by India spurred it to acquire nuclear weapons. In May 1998, India announced two sets of nuclear tests, and Pakistan responded with a series of nuclear tests (Malik 1998), "bringing South Asia's nuclear-armed reality into the open" (Pillalamarri, 2015). Since then, both countries have engaged in an arms race that has outpaced traditional nuclear rivals. Both countries have been accepted as de-facto nuclear states (Arms-control 2003). Decades of competition and mistrust have left Pakistan and India in possession of thousands of nuclear weapons. Both nations are continuously enhancing their nuclear arsenals in the fear that the other will attack. This arms race has occurred because both countries are too fearful to attack first, 
and if one country attacks, it is certain the other will retaliate. An example of this retaliation occurred in a confrontation between the two countries in the last week of February 2019, when both countries carried out air strikes against each other. This made the situation in South Asia very dangerous, and it could ignite a nuclear war between the two countries. If both countries fight another war, it may turn into a nuclear one consciously or incidentally (Wilson and Saetren 2019). Nuclear weapons, if used, will damage the entire region, with immense physical and material consequences for the whole world.Nuclear war is more likely to occur in South Asia than in any other place in the world due to the many disputed issues between Pakistan and India.

\section{The Prisoner's Dilemma Scenario}

Game theory can be used to analyze the arms race between these two countries and has been widely applied to arms race situations. In particular, the prisoner's dilemma (PD) game has been frequently applied to describe such arms race scenarios. Both Pakistan and India are in a "prisoner's dilemma" in their arms race. In this situation, two governments, let us call them two "players" i.e. Pakistan and India, must decide whether to defect or cooperate. The prisoner's dilemma can be seen in the following $2 \times 2$ table where Pakistan and India are two players. In this game, we can say that each player has an option to: cooperate, which will be represented by " $C$ "in this game, ordefect, which means "not cooperate" and will be denoted as" ${ }^{\prime \prime}$ in the given table.

\begin{tabular}{ccc}
\hline & \multicolumn{2}{c}{ The Prisoner's Dilemma } \\
\hline & India Cooperate & India Defect \\
\hline \multirow{3}{*}{ Pakistan Cooperate } & C, C $(3,3)$ & C, D $(1,4)$ \\
& Peace & Strategic edge of India over \\
& Pakistan \\
\hline \multirow{3}{*}{ Pakistan Defect } & Pareto-optimal solution) & D, D $(2,2)$ \\
& Strategic edge of Pakistan $(4,1)$ & Unending arms race/hot \\
& over India & war/Cold War(Nash \\
& & Equilibrium) \\
\hline
\end{tabular}

The interpretation of all four outcomes in the given payoff matrix starts in the upper left corner and moves towards the right. If both countries choose to "cooperate" CC, then both players are not engaged in an arms race, which will bring peace. If Pakistan chooses to "cooperate" and India chooses to "defect" CD, then India gains a power advantage over Pakistan. If Pakistan chooses to "defect" and India chooses to "defect" DD, then both players are involved in an arms race. Lastly, if Pakistan goes with "defect" and India goes with "cooperate" DC, then Pakistan will have a strategic advantage over India.

Now, we need to decide about both players' strategy and how they give their preferences to these outcomes; for example, what is the first choice, the second, 
the third, and the least favoured result? Pakistan's most favoured outcome is DC, where it defects and India cooperates because in this outcome Pakistan gains a power advantage over India. Pakistan can take advantage of India's lenient policy and will act selfishly for its payoff to enhance its security. Pakistan's least favoured result is CD because this result will give India a strategic advantage over Pakistan. Pakistan will suffer because of fear of a strategic edge in the region. Pakistan's security is therefore diminished in this situation. We have the most favoured and the least favoured results. Where do the other two results fit in? Pakistan prefers CC to DD and in such a case in which both players defect and both players cooperate, their relative power stays constant. However, if both players choose to defect, each spends money on building arms that could be utilized for the development of both nations. In this way, CC is superior to DD because Pakistanis not spending its money. It is also clear that Pakistan's favourite choice of outcomes is CC and DD rather than DC because with DC Pakistan gains a relative power advantage over India. Last, Pakistan prefers CC and DD to CD because under CD, Pakistan experiences a power loss. In this manner, the preference order that is suitable for Pakistanis DC $>$ CC $>$ DD $>$ CD.

Using the same logic, India's rational response to any action by Pakistan would be to act unilaterally.In this prisoner's dilemma symmetric game, the other player, for example, India in this case, faces precisely the same situation as Pakistan. Because India faces the same situation as Pakistan, the payoff order will be the same as for Pakistan but with small differences. Like Pakistan, India's most favoured result is the outcome where India gains a relative strategic advantage over Pakistan; this is the outcome CD. Furthermore, like Pakistan, India's least favoured result is the one in which Pakistan gains a strategic advantage; this is the outcome DC. Consequently, India's preference is the same as Pakistan's preference with little difference, but the preference order that is suitable for India is reversed: CD $>$ CC $>$ DD $>$ DC.

\section{The Outcome of the Prisoner's Dilemma Analysis}

What methods will India and Pakistan use in the prisoner's dilemma game, what choices do they have, which choices will they select, and what results would good for us to anticipate? In this prisoner's dilemma game, each player has a "dominant strategy". This can be seen by comparing Pakistan's best choices to India's best choices. In the event that India chooses to "cooperate," Pakistan has to choose between whether to defect or to cooperate. If Pakistan chooses to "cooperate" because of India's decision to defect, Pakistan gets its second most favoured outcome. If Pakistan decides to choose to defect in response to India's choice to "cooperate," Pakistan gets its most favoured outcome. Consequently, if India chooses to cooperate, Pakistan's best reaction is to defect. Now, assume that India decides to defect. If Pakistan chooses to "cooperate" in response to India's choice to defect, Pakistan gets its least favoured outcome. If Pakistan decides to defect considering India's choice to defect, Pakistan gets its second least-favoured outcome. Thus, if India defects, Pakistan's best reaction is to defect. In this 
prisoner's dilemma game, therefore, the decision to "defect" provides Pakistan with more payoff than to "cooperate" irrespective of India's strategy. Therefore, the choice to "defect" is said to "dominate" the strategy to "cooperate" in this game. To defect is always preferred to cooperate.

Since the prisoner's dilemma is symmetric, to defect is also India's "dominant strategy". Because both Pakistan and India players have a "dominant strategy" to defect, this prisoner's dilemma game always provides the same result when both players defect, and the game delivers the DD outcome. Hence, it is proved after discussing all the options that both players will try to choose the dominant strategy, which is to defect. In other words, the prisoner's dilemma game suggests that India and Pakistan will likely stay engaged in arms races to enhance their nations' security.

\section{The Possible Outcomes of a Dominant Strategy}

There are four possible outcomes of the defect-defect situation in this game.

First is the "Pareto sub-optimal outcome which is a concept of efficiency used in the social sciences to conceptualize social welfare" (Ingham 2019).A result is "Pareto optimal when no single individual can be made better off without in the meantime making another individual worse off. Therefore, Pareto sub-optimal refers to the result in which it is possible for at least one individual to understand a welfare development without making any one else in that society worse off" (McMillan 1986). In this situation, the defect-defect outcome is Pareto sub-optimal on the grounds that both players are in an ideal situation when the outcome (better payoff) is CC rather than the outcome DD. Both players prefer to cooperate if both parties know each other's options in advance. Both countries have made several attempts to improve their relationship; for example, the SAARC (South Asian Association for Regional Cooperation) was founded to promote regional development and integration in South Asia but has failed to address the key issues. Many other attempts from which the Shimla Agreement, Tashkent Agreement, Agra Agreement, and Lahore Declaration are the most significant efforts have been made between both countries (Javaid and Khushboo 2017) but have not been able to establish trust between each other and have failed to build peace. Thus, in the absence of mutual trust, both players renege on their initial commitment to cooperate and will act unilaterally. Thus, rational behaviour with respect to each individual player, each of which chooses their dominant strategy to "defect", delivers a sub-optimal collective outcome so India and Pakistan are engaged in an arms race, though they both would have a better payoff if they both cooperate.

The second outcome is DD, which is "Nash equilibrium". This is a state in which both players in a prisoner's dilemma game defect and adopt a dominant strategy regardless of the other player's preference, which often leads to an unending situation. In brief, if both players end up in a position where they choose to not cooperate rather than cooperate on an issue, it is called Nash equilibrium 
(Osborne 2003). If one player believes the other will act unilaterally, his or her best option will be to do the same.If Pakistan changes its strategy from defect to cooperate, the outcome shifts to CD, which is Pakistan's least favoured outcome. In this manner, Pakistanis not getting any benefit if it changes its strategy individually. If India moves its choice from defect " $\mathrm{D}$ " to cooperate " $\mathrm{C}$ ", the outcome would change to DC, which is India's least favoured outcome. So, India is not getting any benefit from changing its choice individually. Both Pakistan and India have no incentive to change their choices individually once they reach the DD outcome of defect-defect in which case the situation is Nash equilibrium.

The third point is a TFT (Tit-for-Tat) strategy, which is a situation involving both nations' relations. In this strategy, the first time, neither party can know what the other will do and can only make assumptions based on previous actions. Both players will also be reluctant to choose any options in advance. Therefore, retaliation will be based on the other player's moves, and trust becomes more prominent in the strategy they choose. There have been several examples discussed before in which both countries tried to cooperate first but defected later and opted to use this strategy, which leads to an uninterrupted series of unrewarding mutual defections. Since the partition of India, both countries have been following a tit-fortat strategy. In this strategy, both players initially intend to cooperate but do not take risks after defection from other players. Axelrod's result after conducting various tournaments was the TFT (Tit-For-Tat) strategy in this PD game. Based on those results, he believed this strategy is the most favoured choice in the prisoner's dilemma, and most of the players play this game using this strategy because this strategy gives the most strategic payoff (Axelrod 2006). Using this strategy, players are not certain about the moves of others, and they cannot take the risk of believing in others in the absence of trust. A good example of the use of this strategy is Pakistan and India's relations. In the history of both nations, several events have occurred based on this strategy. The first happened when India conducted its first nuclear test in 1974 (Izuyama and Ogawa 2003), which was the major reason why Pakistan acquired nuclear capabilities, as it wanted to counter the "fear of India's superior conventional" (Graham 2011)forces. This was the first defection that was reciprocated and can be labelled as an interpretation of this TFT strategy. In the second event, in May1998, India tested nuclear weapons (Ibid.), which left Pakistan with no options, as due to public pressure, Pakistan conducted its own nuclear test a few days later in a tit-for-tat reaction (Ibid.). In May 1999, there was a defection from Pakistan. It started with the infiltration of the Pakistani army and Kashmiri Mujahidin (a group of alleged freedom fighters) into India's territory. India reacted, and the Kargil War broke out. India suspended all ties and bilateral relations with Pakistan in response to this defection, which fit with the tit-for-tat strategy (Joeck 2008). In 2002, another incident occurred between the two countries when India accused Pakistan of attacking its parliament through terrorism and brought its onemillion-man force along the Pakistani border. In reaction, Pakistan also brought all its forces to the border. This was one of the largest military stand-offs between Pakistan and India (Ibid.). The most recent defection was the best example of this strategy, as a tit-for-tat action occurred in the last week of February. On February 26, 
2019, India claimed that its air force had entered Pakistan and targeted camps of those that had caused the February 14 suicide attack in Indian-occupied Kashmir. This was the first time since the 1971 war that Indian jets had violated Pakistani airspace. On February 27, Pakistan claimed that its air force had conducted strikes on "non-military targets" in India (Helen and Kumar 2019). The two nuclear states have been engaged in a tit-for-tat strategy for many decades, and this situation could escalate into a nuclear war, posing a grave threat to the world. How can we think of ways to make the world peaceful when thousands of nuclear warheads exist, even though only a few nuclear weapons would be enough to commit selfdestruction (Kirk)? After examining different situations in which this strategy applies, it has been well understood on both sides that they cannot get a cooperative outcome after committing even a minor defection, and they will get the same response of defection.

The fourth point preventing both players (Pakistan and India) from realizing that the expected gains from cooperation are the absence of a proper mechanism for enforcing an agreement and the role of third-party mediation. Thomas Hobbes (1588-1679), a famous political philosopher, believed that the only way out of a situation such as this is to have a mechanism in place that ensures that individuals cannot defect, and some way of enforcing the agreements or contracts is established by imposing sanctions on those who break them. If there were such a third party, which could be any international power/body, to convince both nations to try to enforce an agreement with mutual consent with the guarantee of international powers, then it could be possible for both players to cooperate and escape this situation, which seems the most appropriate and best outcome in this situation. But for this outcome, an effective and credible institution is needed to help India and Pakistan come to agreements and enforce penalties if the agreements are violated. Both agree to abide by the agreement, but in the current international scenario, there is no institution or third party that seems to have the capability to enforce any agreements without solving their disputes. The current system on the international level, therefore, gives encouragement to both players to engage in arms races, which is making it difficult for both players to reach peace and end the arms race. The influence of external powers such as China, Russia and western powers including the USA in the South Asian region remains a matter of discussion because the intense rivalry between India and Pakistan has always attracted external powers that want to take advantage of their rivalry. The recent confrontation between Pakistan and India highlights the need for intervention from major powers to move towards fulfilling their obligations under the Non-Proliferation Treaty (NPT). If the confrontation reaches a point where nuclear war breaks out, then it would not only affect this region but the whole world. According to a study conducted at the University of Colorado, if Pakistan and India employed their nuclear weapons, the expected impact would be the loss of at least 45 million people, with the spreading smoke plunging the world into a 25-year-long nuclear winter (Hallinan 2019). If both countries do not resolve their disputes, it could end in a nuclear war, which is a grave threat to the world. South Asia is considered the world's most likely nuclear 
flash point (Mahmood 1998). According to the Stockholm International Peace Research Institute (SIPRI) report from 2014, the five biggest exporters of arms in 2010-2014 were the US, Russia, China, Germany, and France. Interestingly, Pakistan and India are among the five biggest importers according to this report. Could any rational person believe that any exporter wants to lose its business? The tension between Pakistan and India can be better understood in terms of this international political system, which is the major cause of their security problems. "India and Pakistan have been forced into power politics on account of the anarchic nature of the international system" (McLeod,2008).Thus, it is impossible to say in this situation whether those powers can play any role in convincing Pakistan and India to disarm.

Considering the above situation, this game provides an understanding of why both players are adopting the dominant strategy in which players find themselves stuck in an unending arms race, and why both sides cannot reach a better payoff to change their behaviour to end the arms race. Although everyone recognises the consequences of the arms race, which is a major cause of the two countries' limited economic growth, the possession of nuclear arms is viewed as a form of deterrence and national strength in both countries (Sagan 1995). The nuclear arms race provides a good scenario of the problem of cooperation. This can be best understood in the abovementioned situations in which two parties (Pakistan and India) can either cooperate or defect. Even though India and Pakistan would both gain a better pay off through cooperating and both players agreeing to limit their nuclear arms and stop their nuclear programs, both players will continue in their arms race due to weak international mechanics. Thus, the prisoner's dilemma highlights the weaknesses in the international system and demonstrates how a lack of trust between both states and the current nature of power politics are major causes of the way players behave in international politics.

\section{United Nations' New Disarmament Plan and Challenges}

The only option left is to rely on the help of the United Nations, as almost all the world's nations consider the UN as a problem solver. In the very first resolution in 1946, the United Nations General Assembly required the formation of a commission to manage issues related to the disclosure of nuclear energy among countries. According to the website on arms control, more than 28 treaties and agreements have been introduced in the last 60 years to enforce the disarmament policy and make the world a more peaceful place (Armscontrol). The United Nations Office for Disarmament Affairs (UNODA) was established in January 1998 to promote nuclear disarmament and non-proliferation (UN News). Recently, the United Nations has promoted a similar strategy with a new approach: during an address at the University of Geneva, the UN chief announced a new agenda entitled "Securing our common future". As he asserted, this time, a new plan would employ more practical measures over the whole scope of disarmament issues. He said "Disarmament prevents and ends violence. Disarmament supports sustainable development and disarmament is true to our values and principles" (UN News). 
Most of the world's citizens view nuclear weapons adversely, which bolsters the objective of nuclear disarmament, at least in principle. If we are not serious about considerations toward the actual issue, we will not truly work toward disarmament. Why are India, Pakistan, (Smith 2018) Iran, Turkey, (Arab News 2017) and North Korea (Papenfuss 2018) in a competitive defence race? Why is Japan expanding its military spending? (Wakatsuki and Westcot 2018) Why is Israel, with its tiny landmass, considered a powerful military country? (Bachner 2018) Why are Arab nations attempting to expand their military spending? (Gaub and Stanley-Lockman 2017)Why are nations in South America and Europe expanding their military spending? (Statista) Is it possible to believe that the new agenda can work in this scenario in any part of the world, including South Asia? We must be realistic and ask: Why is it acceptable for nuclear weapons to be in the hands of the US and Russia, but not in those of Iran, North Korea, Pakistan and India? The nuclear arms race is not limited to these rivals in South Asia, as India has a fear of a nuclear China, and China needed to develop its nuclear program to match the US, while the US needed to have it because of Russia (Booth \& Wheeler 2008). It is difficult to state that this issue is present only in South Asia. If, for instance, Pakistan and India resolved their issues, would India stop its nuclear program, or would it simply focus more on China's nuclear program? The pursuit of disarmament ought to be implemented with respect to all countries, in the same spirit. In other words, we should eliminate the "double standards" that exist in regard to disarmament. The rules should apply to all countries that have nuclear weapons or are trying to achieve this capability as they try to gain a strategic edge over their rivals as is seen in South Asia between India and Pakistan. Indeed, the new agenda could work if the United Nations could address certain issues. The world badly needs another approach to disarmament. Although a wide range of proposals have been put forth, the actual issues can only be addressed through consensus, not power. The question is then, what are the actual issues? Promoting equity and balance inside the United Nations, debating veto rights, promoting humanism in extremist societies and resolving disputed issues on priority could all work towards reinstating the credibility of the United Nations. Then, any commonly agreed upon plan could be imposed on the world with stronger chances of success. The United Nations should make bold strides rather than temporary plans. Due to religious factors, the most dangerous threats lie in South Asia and the Middle East. India's biggest political party, BJP, is highly radicalized (Choudhury 2018). Pakistan, Israel, (Tabassum 2018) and Iran (Bruno 2018) are highly perilous in terms of religious fanaticism, and nobody can persuade those countries to embrace disarmament without addressing the core issues in the region. The U.S. declared that it would withdraw from its atomic arms control treaty with Russia, which is raising feelings of trepidation regarding the risk of another global arms race (Gearan, Sonne, and Morello 2017). How the United Nations can deal with these countries is a major question. The United Nations should concentrate on these issues if it wants its agenda to be successful, not only in South Asia but across the world. 


\section{References}

Anderson, Lisa R., \& Mellor, Jennifer M. (2008). The Economic Approach to Cooperation and Trust: Lessons for the Study of Social Capital and Health. In Social Capital and Health, edited by Ichiro Kawachi, S.V. Subramanian, and Daniel Kim, New York: Springer.

Arab News. (2017). Iran and Turkey agree to increase military cooperation. [online] Available at: http://www.arabnews.com/node/1146561/middle-east

Armscontrol.org. Treaties \& Agreements | Arms Control Association. [online] Available at: https://www.armscontrol.org/treaties [Accessed15 April 2019].

Axelrod, Robert. (2006).The Evolution of Cooperation, Revised Edition. New York: Basic Books.

Bachner, M. (2018). Israel ranked 8th most powerful country in the world. [online] TimesofIsrael.com. Available at: https:/ / www.timesofIsrael.com/Israel-ranked8th-most-powerful-country-in-the-world-survey/

Booth, K., \& Wheeler, N. (2008).The security dilemma, Palgrave Macmillan, New York,

Bruno, G. (2018). Religion and Politics in Iran. [online] Council on Foreign Relations. https://www.cfr.org/backgrounder/religion-and-politics-iran

Choudhury, Z. (2018). India into the quicksands of radicalism. [online] Dhaka Tribune. https://www.dhakatribune.com/opinion/2018/02/01/Indiaquicksands-radicalism [Accessed 1 Apr. 2019].

Dan, Lindley. (1999). https://www3.nd.edu/ dlindley/handouts /gametheory.html.

Gaub, F. \& Stanley-Lockman, Z. (2017). Defense industries in Arab states: players and strategies. [online] Iss.europa.eu. https://www.iss.europa.eu/sites/ default/files/EUISSFiles/CP_141_Arab_Defence.pdf

Gearan, A., Sonne, P. \& Morello, C . (2019, February, 1). National security, The Washington Post.

Graham, T. (2011). Nuclear weapons stability or anarchy in the 21st century: China, India, and Pakistan. New York, NY: Brookhaven National Laboratory.

Hallinan, C. (2019). Nuclear Powers Need to Disarm Before It's Too Late. [online] Foreign Policy In Focus.

Helen, Regan, \& Nikhil Kumar. (2019, February, 27). Pakistan Says It Shot Down Two Indian Jets as Kashmir Border Crisis Deepens. CNN. 
Ingham, Sean, (2019). "Pareto-Optimality | Social Sciences". Encyclopedia Britannica.

Izuyama, M. \& S. Ogawa, (2003). The nuclear policies of India and Pakistan, The Japanese National Institute for Defense Studies Reports No. 4, (2003).

Javaid, Umbreen, \& Ejaz, Khushboo (2019). The Agra Summit: A Critical Appraisal" JPUHS 30:1 (2017) 243-259

Joeck, N. (2009). The Indo-Pakistani Nuclear Confrontation: Lessons from the Past, Contingencies for the Future." In Pakistan's Nuclear Future: Reigning in the Risk, Edited by Henry Sokolski, Carlisle: Strategic Studies Institute,

Kirk, A. (2017). How many nukes are in the world and what could they destroy? [online] The Telegraph. https://www.telegraph.co.uk/news/0/many-nukesworld-could-destroy/

Köchler, H. (2006). The United Nations Organization and Global Power Politics: The Antagonism between Power and Law and the Future of World Order. Chinese Journal of International Law.

Levitt, J. (2014). Pearson and Canada's Role in Nuclear Disarmament and Arms Control Negotiations, 1945-1957, Montreal: McGill-Queen's University Press.

Mahmood, T. (2008). UN and Nuclear Issue in South Asia. Pakistan Institute of International Affairs 51:2 71-81

Malik M. (1998).India goes nuclear: Rationales, benefits, costs, and implications Contemporary South East Asia 20(2)

Malvern Lumsden, (1973). The Cyprus Conflict as a Prisoner's Dilemma Game, Journal of Conflict Resolution 17, 8

McLeod, D. (2008). India and Pakistan: Friends, rivals or enemies? Ashgate, Bristol, UK

McMillan, John, (1986). Game Theory in International Economics: Harwood Fundamentals of Applied Economics. Harwood Academic Publishers Chur, Switzerland,

Osborne, Martin J. (2003). An Introduction to Game Theory. Oxford University Press.

Papenfuss, M. (2018). North Korea Boosting Nuclear Fuel Production At Secret Sites: Report. HuffPost Canada.

Peña, C. (2007). Nuclear Nonproliferation in the Post-9/11 World. Independent.org. 
Pillalamarri, Akhilesh (2015). India's Nuclear-Weapons Program: 5 Things You need to Know. https://nationalinterest.org/feature/Indias-nuclear-weaponsprogram-5-things-you-need-know-12697?

Plous, S. (1993). The Nuclear Arms Race: Prisoner's Dilemma or Perceptual Dilemma? Journal of Peace Research 30:2, 163-179.

Roach, K. (2011). The UN's Failed Response to 9/11 | University of Toronto Faculty of Law. Law.utoronto.ca.

Sagan, S. (1995). Why do states build nuclear weapons: Three models in search of a bomb" International Security, 21(6)). 54-86.

Smith, R. (2018). 2018-2019 Defence Budget of India, Pakistan, Bangladesh, and Myanmar. Medium.com.

Tabassum, R. (2018). Tale of Two Religious States. Newsweek Pakistan.

UN News. (2018). UN chief launches new disarmament agenda 'to secure our world and our future'. https://news.un.org/en/story/2018/05/1010551

Wakatsuki, Y.\& Westcott, B. (2018, August, 31). Japan military budget grows for the seventh year in face of North Korean threat. CNN.

Wilson, G. \& Saetren, W. (2019). India and Pakistan on the Brink: A Nuclear Nightmare in South Asia. The National Interest. 